\title{
FROM THE SUBLIME TO THE ORDINARY: STANLEY
}

\section{CAVELL'S BECKETT}

'Beckett shrugs his shoulders at the possibility of philosophy today.' So claims Theodor Adorno in his rather abortive 'Versuch, das Endspiel zu verstehen. ${ }^{1}$ And yet, perhaps because of this very act of shoulder shrugging, the works of Samuel Beckett seem to have fired the imaginations of a great many philosophers. Discussions of Beckett feature prominently in the writings of such thinkers as Gilles Deleuze, Maurice Blanchot, Alain Badiou, and, of course, Theodor Adorno, and current work in Beckett studies has been dominated by contemplating, clarifying, and extrapolating these philosophical readings. ${ }^{2}$ A recent book by Richard Lane, entitled Beckett and Philosophy, is divided into a section mapping out Beckett's significance for an array of French philosophers, and another section mapping out the same territory in German philosophy. ${ }^{3}$

Tellingly, there is no third section on Beckett's significance for Anglo-American philosophers, despite the fact that his works have drawn comment from leading thinkers like Martha Nussbaum and Stanley Cavell. ${ }^{4}$ Indeed, since the publication of Must We Mean What We Say? forty years ago, Cavell's essay on Endgame has attracted the attention of only the smallest handful of commentators - a fraction of those who have written on Adorno's essay on the same subject. My aim in this paper will be to take some steps towards redressing this imbalance, by teasing out some of the implications of Cavell's position. 
I want to start by taking a few caveats from Simon Critchley, one of the select few philosophers to have taken Cavell's reading of Beckett seriously. Critchley begins his philosophical discussion of Beckett with the following words of warning:

The writings of Samuel Beckett seem to be particularly, perhaps uniquely, resistant to philosophical interpretation. ... [H]is texts continually seem to pull the rug from under the feet of the philosopher by showing themselves to be conscious of the possibility of such interpretations; or, better, such interpretations seem to lag behind the text which they are trying to interpret; or, better still, such interpretations seem to lag behind their object by saying too much: something essential to Beckett's language is lost by overshooting the text and ascending into the stratosphere of metalanguage. ... [I]t might well be that philosophically meditated meanings are precisely what we should not be in search of when thinking through Beckett's work. ${ }^{5}$

Critchley characterises the danger besetting those of us who try to read Beckett philosophically as 'saying too much and saying too little, saying too little by saying too much' (Critchley, p. 144). This is a warning we would do well to heed - a satisfactory approach to Beckett, it seems, must navigate between a Scylla 
and a Charybdis: on the one hand, the temptation to conclude that Beckett's works are essentially meaningless; and on the other, the compulsion to read into them layers and levels of supposedly 'deeper', pseudo-philosophical, metaphysical meaning. It is between these two extremes - distant cousins, I suspect, of skepticism and metaphysics - that Cavell's reading of Beckett tries to plot its course, while acknowledging both the temptation and the compulsion that would lead it astray.

Perhaps the most striking aspect of Cavell's reading of Beckett is its insistence on taking Beckett as literally as possible. ${ }^{6}$ Cavell steers deftly between the argument that Beckett's plays are meaningless and the argument that they have a supposedly 'deeper' metaphysical meaning by pointing out that, as often as not, Beckett's characters mean exactly what they say. Endgame is suffused with a property that Cavell terms 'hidden literality' (MWM, p. 119) - as in:

HАMм: Did you ever think of one thing?

Clov: Never.

or:

CLOV: Do you believe in the life to come?

HAMM: Mine was always that. ${ }^{7}$

This is what Cavell calls 'Beckett's uncovering of the literal' ( $M W M$, p. 120), and it is directly related to the claims he makes about the ordinariness of Endgame. As Cavell puts it: 'the sort of method I try to use consistently in reading the play, [is] one in which I am always asking of a line either: What are the most ordinary circumstances under which such a line would be uttered? Or: What do the words literally say?' (MWM, p. 121). This strategy might reasonably 
be expected to stave off the threat of skepticism, but I find it does rather the opposite. Faced with an assertion like: 'Beckett's plays mean nothing more and nothing less than what they say', a skeptic (or, for that matter, a bemused undergraduate) might reasonably respond with the question 'And what is that?' A meaningful answer to this question could well prove difficult to give.

How, then, are we to read Endgame? All too often, critics and philosophers spill rivers of hermeneutic ink in seeking to persuade themselves and others that they have uncovered a meaning to a literary text that is more than is said by the words at first sight. This exposes their widely held, problematic suppositions that our words can or could mean more than they say, opening up a metaphysical dimension for meaning, in which proliferate unresolvable arguments about which supposedly 'deeper' meaning the text is supposedly 'really' about. It goes against more or less the entire bent of Cavell's thought to do this - particularly when the text under discussion is as enigmatic as Beckett's Endgame. Yet critics of Cavell have pointed out that this is precisely what he does in his own reading: in his essay, Hamm and Clov's shelter becomes Noah's ark; the play takes on the force of a theological parable on eschatology; and its eschatological dimensions evoke the spectre of nuclear holocaust (see $M W M$, pp. 132-55). For Jay Bernstein at least, Cavell's reading of Beckett fails to practice what it preaches. ${ }^{8}$ But this isn't the problem it seems at first blush. These excursive flights into exegesis surely exemplify the crux of Cavell's case: that there is a deep-seated compulsion to see into Beckett's words something more than they say, a need to get from them more than they have given us. As Cavell puts it: 'We have to talk, whether we have something to say or not; and the less 
we want to say and want to hear the more wilfully we talk and are subjected to talk' $(M W M$, p. 161). To put it another way, Cavell successfully argues that there is no contradiction between Beckett's lack of faith in words and his going on to use them (see $M W M$, p. 161). By the same token, there is no more contradiction in Cavell advocating that we take Endgame literally, and his going on to read it allegorically.

In any case, for much of his essay, Cavell argues not that Beckett's play is incapable of meaning something more than it says, but rather the opposite: that it is incapable of meaning anything less; that it is incapable of attaining the status of meaninglessness ascribed to it by so many critics. As Cavell puts it, 'The discovery of Endgame, both in topic and technique, is not the failure of meaning (if that means the lack of meaning) but its total, even totalitarian, success - our inability not to mean what we are given to mean' $(M W M$, p. 117). It is this claim that strikes me as the most interesting aspect of the essay, and one that, along with the following assertion, invites further discussion: 'Solitude, emptiness, nothingness, meaninglessness, silence - these are not the givens of Beckett's characters but their goal, their new heroic undertaking' ( $M W M$, p. 156).

Simon Critchley glosses these claims by relating them to the role of the ordinary in Cavell's thought. That is, Endgame is anchored in what Cavell highlights as the 'ordinariness' (p. 117) of its events and its language, but that does not, in and of itself, stabilise its meaning or make it straightforward. Rather, for Critchley, here as elsewhere in Cavell's thought, 'the ordinary is the object of a quest, a task, something to be achieved and not an available fact' (Critchley, p. 
178). According to Critchley, 'On Cavell's reading, Beckett is not telling us that the universe is meaningless, rather meaninglessness is a task, an achievement, the achievement of the ordinary or the everyday' (p. 179).

Perhaps the obvious question to ask here would be: is this task achieved? Is this goal ever reached? Everything about Cavell's position seems to imply that the answer to this question is, and must necessarily be, no. If, as Cavell has it, Beckett's play is indeed imprisoned within the totalitarian confines of inescapable meaning, then the possibility of breaking free of these shackles does not and cannot arise. To think otherwise would be to lapse into the delusion that Beckett's words could somehow avoid meaning what they say. Moreover, if the answer were yes, then Endgame might indeed aspire to the condition of meaninglessness, an argument from which Cavell distances himself at the start of his essay, describing it as 'impositions from an impression of fashionable philosophy' (MWM, p. 115).

It may seem perfectly in tune with the spirit and timbre of Beckett's plays to see within them an ongoing task that can never be accomplished, a distant goal that can never be achieved. But it is nonetheless a questionable move. Critchley's suggestion may encapsulate the predicament of Hamm and Clov perfectly, and it may well describe our experience in watching them, and perhaps that is all it needs to do. But, by implication at least, it lines up Beckett alongside the likes of Emerson, Thoreau, Wordsworth, Coleridge, Wittgenstein, Austin, and Cavell himself, for whom to be in quest of the ordinary is to be in quest of the unattainable. It seems to me that there is something qualitatively different about 
what Beckett does that sets him apart from these writers and thinkers. I would suggest, pace Critchley, that Beckett's characters are not so much in quest of the ordinary as imprisoned within it, and their impossible task is not so much achieving the ordinary but aspiring beyond or beneath it. That this is an unattainable quest, an impossible task, is, perhaps, the tragedy of the everyday. ${ }^{9}$

Ultimately, whichever of these versions of Beckett we prefer, there are limits to an approach that takes Beckett too literally, and these are limits that are implicit in Cavell's own discussion. After charting the forms of hidden literality found in Endgame, Cavell goes on to diagnose a very different form of meaning in the play, in which the words do indeed seem to mean more than what they say. It is described as 'the way an utterance which has entered naturally into the dialogue and continues it with obvious sense suddenly sends out an intense meaning, and one which seems to summarise or reveal the entire drift of mood or state of mind until then unnoticed or unexpressed' ( $M W M$, p. 128). One of the examples Cavell gives of such a 'climactic exclamation' (p. 149) is Hamm's enigmatic line 'To think it won't all have been for nothing' (Beckett, p. 108). Reflecting on the experience of such lines, Cavell says 'It would not be quite right to say that something was revealed; but there was as it were an air of revelation among us' (MWM, pp. 128-9).

Cavell is undoubtedly right to hear such moments with a sense of revelation about them peppered throughout Beckett's works: indeed, one can hardly watch a performance of Endgame without hearing them. But these moments might be seen as problematic for an approach that tries to take the play 
literally: they seem to imply that, at times, Beckett's words have the capacity to reveal something more than what they say, and yet that something is not necessarily a meaning that is recuperable within ordinary language. As a Wittgensteinian might put it, 'It is not a something, but not a nothing either!'10 Are these abortive epiphanies in Beckett's prose troublesome for an approach that takes as its working assumption the premise that his words mean no more and no less than what they say? In the next part of my paper, I want to explore this question with reference to what James Noggle has called 'The Wittgensteinian Sublime'.

\section{II}

Noggle takes one of the most traditional concepts associated with aesthetics - that of the sublime - and rethinks it in terms of the Wittgensteinian ideas of language games and the limits of language. Such a move might at first blush seem uncongenial to the bent of the Philosophical Investigations. After all, Wittgenstein warns us against the 'tendency to sublime the logic of our language' and against the 'tendency ... to purify, to sublime, the signs themselves' (Wittgenstein, §38; §94). But elsewhere he says 'These considerations bring us up to the problem: in what sense is logic something sublime?' (§89). This is indeed a good question to ask of the author of the Tractatus LogicoPhilosophicus. Noggle suggests that the vast, undiscovered country wovon man nicht sprechen kann is best thought of as the territory of the sublime. To use the well-known example of Tractatus 6.421:

It is clear that ethics cannot be put into words. 
Ethics is transcendental.

(Ethics and aesthetics are one and the same. $)^{11}$

This is a clear instance of the classic bind of the Tractatus: on the one hand, we are aware of a vast, transcendental realm that appears to harbour all the metaphysical truths of philosophy; yet, on the other, we are aware that this realm remains unattainable, incomprehensible, unspeakable, since, as Wittgenstein has just warned us in Tractatus 6.42, 'Propositions can express nothing that is higher'. For Noggle, this bind is closely analogous to the concept of the sublime. He argues:

Our attempts to venture beyond language games ... posit a supersensible domain of discouse ... But as Wittgenstein says, our apprehension of this domain is illusory. We attain an illusion of transcendence similar to the illusion experienced in the sublime, where the saturation of our cognitive or perceptual faculties seems to present the infinitely mighty or vast, but in fact can indicate no more than our inability to cognise or perceive infinitely. ${ }^{12}$

The experience of the sublime, it will be remembered, is not an experience with any positive content whatsoever: it is an experience of our incapacity to comprehend or to articulate it. Noggle compares it to what Wittgenstein calls the 'bumps that the understanding has got by running its head up against the limits of language'. ${ }^{13}$ This remark in turn suggests how the experience of the sublime is, perhaps surprisingly, intimately related to the realm of ordinary language. As Noggle argues:

In [Wittgenstein's] later work, philosophical utterances 'sublime the logic of our language' not because they gesture outward toward some 
ineffable but metaphysically significant realm beyond the ordinary. Rather, they are an effect of language's failure to do so, to hint at anything truly metaphysical, truly beyond ordinary language games. Much as sublime experience according to Kant's third Critique offers not a true image of absolute power or the infinite universe but rather an instance of our failure to grasp such things, language 'outside language games' is an outward venture that leads us nowhere but backward, to the untranscendental conditions of ordinary language which is all there is ("WS", p. 609).

Or, to put it more succinctly, 'Sublime language is a leap away from the ordinary, not into some alternative language of metaphor but into the void of meaning' ("WS", p. 614). And yet, of course, we find ourselves compelled to attempt such leaps, in spite of - perhaps even because of - their futility. Like characters in a Beckett play, we strain to reach beyond the ordinary, though doing so can only result in meaninglessness. ${ }^{14}$

Noggle compares the experience of the Wittgensteinian sublime with Cavell's emphasis on encountering the limits of language games: 'For Cavell, only by departing from language games can we grasp their significance' ("WS", p. 607) - which is not to say or imply that there is anything 'beyond' or 'outside' language games that we grasp instead. Such ventures are rather '(attempted) departures from that from which we "cannot" depart' ("WS", p. 613).

To describe the Wittgensteinian sublime in these terms is to recognise that it is fundamental to the question of the limits of language and to the 
meaninglessness that lies beyond everyday language games. Yet it also highlights an interesting dialectical relationship that the Wittgensteinian sublime mediates between ordinary language games and meaninglessness, in that, for Noggle, 'the sufficiency of language games reveals itself only if we subject ourselves to the metaphysical nonsense that would seem to negate them' ("WS", p. 614). This is a position that is very close indeed to Cavell's, as is evident in this short summary: 'Ordinary language is both all the language we ever really have and radically in need of the extraordinary language of metaphysical illusion - which is useful only insofar as it proves from the perspective of ordinary language to be useless' (“WS”, p. 611).

Interestingly, Noggle's delineation of the Wittgensteinian sublime takes inspiration from other aspects of Cavell's work - in particular, a brief but suggestive passage from This New Yet Unapproachable America:

Wittgenstein's appearance at this intersection of romanticism and skepticism and Kant is, so it seems to me, encoded in his concept of subliming. ... But whereas in Kant the psychic strain is between intellect and sensibility, in Wittgenstein the straining is of language against itself, against the commonality of criteria which are its conditions, turning it as it were against its origins. - Thus a derivative romantic aesthetic problematic concerning the sublime moves to the center of the problematic of knowledge, or say wording the world; quite as if aesthetics itself claims a new position in the economy of philosophy. ${ }^{15}$ 
Cavell doesn't specify what this new position might be, but if Noggle is right, then the Wittgensteinian sublime might be that which both designates and demarcates the boundaries of the knowable, the thinkable, and the speakable. To attempt to aspire beyond these, as Hamm and Clov do - as from time to time we all do - is to take on the sublime, to try and bring it within the compass of language and of comprehension: in short, to try to turn it into something like the beautiful.

It is with these terms in mind that I return now to Cavell's literary aesthetic. The attempt, so common in literary texts but by no means peculiar to them, to use ordinary language to gesture beyond itself is, for Noggle, 'best identified as a species of the sublime' ("WS", p. 605). After all, it has long been a critical commonplace that works of literature do their best to depart from the conventions of everyday language games, in quest of more striking meanings, and clearly the Wittgensteinian sublime gives us an intriguing way of conceptualising how they (attempt to) do so. But a sensible objection to my line of argument at this stage would be that, if Cavell is right, then generally speaking Beckett does not do this. Beckett's lines, Cavell argues, generally mean what they say: they ought to be taken literally, as pieces of ordinary language. A similar approach has been argued for in the movement towards a Wittgensteinian literary criticism articulated by Marjorie Perloff and others - that Wittgenstein's emphasis on the everyday helps us to appreciate the creativity of writers from the modernists to the language poets (and she explicitly includes Samuel Beckett amongst them $)^{16}$ who turned deliberately to ordinary language precisely in order to reject poetry's traditional, romantic attempts to get beyond it. Theirs, Perloff 
argues, is an aesthetic of the ordinary - what she calls "the "ordinary language" poetics so central to our time' (Perloff, p. 22) - and the critic should embrace this aesthetic in approaching them. There would not appear to be much room for the Wittgensteinian sublime, or indeed for any other kind of sublime, if we adopt this critical emphasis on ordinary, everyday, literal language.

To think this way, though, is to set up a false opposition between Perloff's 'ordinary language poetics' and Noggle's Wittgensteinian sublime and to misunderstand Cavell's approach to Beckett. For it is in the nature of both Cavell's and Noggle's enterprises that they are neither stable nor sustainable. Both demonstrate, as does Perloff, that an emphasis on ordinary language is allimportant. But the 'ordinary' is not always straightforwardly or readily available in or on its own terms. Indeed, for Cavell, the ordinary is most clearly grasped in the moment of its loss. Just as the Wittgensteinian sublime is an empty territory, a void of meaninglessness where we cannot dwell, and from which we pass back into the realm of the ordinary with a better, more sharply defined sense of its power and its limits, so too the everyday language of Beckett's Hamm and Clov is not and cannot be sufficient unto itself, but inevitably bumps up against the limits of language, as even the most 'ordinary' or 'everyday' work of literature must. To quote Noggle once again:

At such extreme moments, in the Investigations' words, 'language is like an engine idling', disengaged from the language games in which it has its life and therefore alienated from and useless to its user - a state of confusion that Wittgenstein also describes as 'the bewitchment of our intelligence by means of language' 
(Philosophical Investigations §109). But while such linguistic bewitchment or alienation by definition can never be seen as a language game in itself, Cavell's reading of Wittgenstein also stresses that we can never find a way of avoiding it once and for all, that we must confront it repeatedly - and he furthermore persistently suggests that literary works are especially good at provoking such confrontations ("WS", p. 606).

Which is not to suggest that we should risk 'equating good literature with bad philosophizing' ("WS", p. 607). It is rather to acknowledge the near inevitability of overstepping the limits of language and hence passing into nonsense in a literary text, even if - perhaps especially if - that text attempts to confine itself to the ordinary. 'Thus', Noggle says, 'the aesthetic power of language outside language games does not affect us in spite of its distinctness from ordinary concerns but rather consists in it' ("WS", p. 612).

\section{III}

So much for the philosophy: how then to support this argument with reference to Beckett's Endgame, and Cavell's reading of it? Starting with Cavell, towards the end of his essay on Endgame, Beckett's use of words in his writing is described in these terms: 'One could say: He doesn't use them just any way; and even: He doesn't use them at all (for example, to promise, to threaten, to pray, to apologise - the things words are used for) or sees how far he can go in not, in not saying more than the words' ( $M W M, \mathrm{p} 161)$. In a telling choice of phrase, Cavell suggests that Beckett is not so much trying to take ordinary language as far as he 
can go in terms of meaning, but as far as he can go in terms of not meaning something more, not going beyond it - as if acknowledging the inevitability of so doing, or as if the two were inextricably implicated in one another. A similar choice of phrase is in evidence when Cavell tells us that 'To miss the ordinariness of the lives in Endgame is to avoid the extraordinariness (and ordinariness) of our own' ( $M W M$, p. 119). Once again, there is the suggestion here that the ordinary and the extraordinary are linked, and that the sense of each is gained from passing on into the realm of the other.

But, as we see in Endgame, such a transition is an empty one, in that when Hamm and Clov's words manage to depart from the ordinary, the result is a "coupling of their sublimity with their nonsensicality' ("WS", p. 617). Consider this line of Hamm's, taken from his final monologue: 'Moments for nothing, now as always, time was never and time is over, reckoning closed and story ended' (Beckett, p. 133). The first part of the line - "now as always, time was never and time is over' - is a patent self-contradiction, a parcel of nonsense that, however poetic it sounds, says nothing intelligible. It is, I think, as clear an evocation of the unfathomable and incomprehensible nature of time, and hence of the sublime, as William Blake's rather more traditional exhortation to 'Hold infinity in the palm of your hand / and eternity in an hour'. And yet the second part of Hamm's line - 'reckoning closed and story ended' - insists on the limits of knowledge and of language, and seems to draw back from the abyssal depths hinted at in the first part. Perhaps this is nothing more than what Wittgenstein would have called 'The transition from patent nonsense to something which is disguised 
nonsense', ${ }^{17}$ but it nevertheless hints at a transition from the sublime to the everyday.

A similar transition can be seen more clearly in the following piece of dialogue between Hamm and Clov:

HАMм: Go and get the oilcan.

Clov: What for?

HAMM: To oil the castors.

CLOV: I oiled them yesterday.

HAMM: Yesterday! What does that mean? Yesterday!

CLOV: [Violently.] That means that bloody awful day, long ago, before this bloody awful day. I use the words you taught me. If they don't mean anything any more, teach me others. Or let me be silent. (Beckett, p. 113).

This exchange begins as a perfectly everyday, workmanlike piece of conversation. The dialogue about the oilcan and oiling the castors is as ordinary as a builder asking his workmate for a slab, or a customer asking the shopkeeper for five red apples. But something extraordinary enters the conversation with the word 'yesterday': Hamm demands 'Yesterday! What does that mean? Yesterday!'. The obvious way to read this line would be as the interjection of a hard taskmaster: something like 'What's the good of telling me you did it yesterday when I want it done today?'. Hamm throws the word 'yesterday' back at Clov, as if he were scoffing at it. But, of course, given the context of the play, it is also a line haunted by the spectre of metaphysics: it is a kind of philosophical question - 'Yesterday! What does that mean? Yesterday!' It is not 
so much a question as an evocation of the sublime, the incomprehensible mystery of passing time. It broaches the domain of the infinite, and, as a question, it is, of course, unanswerable. But Clov refuses to hear either the scoffing or the evocation: he insists on answering the question literally by providing Hamm with a literal definition of the word 'yesterday' as it is ordinarily used: 'That means that bloody awful day, long ago, before this bloody awful day.' He is, to paraphrase Wittgenstein, bringing Hamm's words back from their metaphysical to their everyday uses, and thereby recuperating them from the realm of the sublime. Or, as he puts it, 'I use the words you taught me. If they don't mean anything any more, teach me others.' Clov's words here recall Cavell reporting Esslin reporting Gessner reporting Beckett's response to a question about the insufficiency of language, to which Beckett replied 'Que voulez-vous, Monsieur? C'est les mots; on n'a rien d'autre' (see MWM, p. 161). And indeed, what else is there? Certainly, there are no more sugar plums, no more bicycle wheels, no more pap, no more pain killer.

If I appear to be investing too much significance here in the word 'yesterday', it is because this same word is used to (attempt to) evoke the same depths by Hamm's mother Nell. Consider, once again, the transition between ordinary, workmanlike language and the evocative use of that word in the following exchanges between Nagg and Nell:

NAGG: I've lost me tooth.

NELL: When?

NAGG: I had it yesterday.

NeLL: (Elegiac.) Ah yesterday! 
[They turn painfully towards each other.] (Beckett, p. 99)

Or, once again:

NAGG: Could you give me a scratch before you go?

NeLL: No. [Pause.] Where?

NAGG: In the back.

NELL: No. ...

NAGG: ... Could you not? [Pause.] Yesterday you scratched me there.

NELL: [Elegiac] Ah yesterday! (Beckett, p. 101)

With this one word - 'yesterday' - Nell passes beyond what Cavell calls her 'girlish re-rhapsodizing the beauties of Lake Como' (MWM, p. 118) and into an abyss of melancholy so deep it cannot be put into words - it can only be hinted at, evoked with the word 'yesterday' spoken (as the stage direction requires) in an elegiac tone of voice. It is as if a whole world of pain is contained in the word and yet that is not how Nagg uses it, nor how Clov defines it, nor how it fits into ordinary language. The world of pain that is contained within the word can never be given form, shape, or content.

I use this turn of phrase - 'a world of pain is contained in the word' because it is how Wittgenstein describes a similar experience. Commenting on Schubert's Death and the Maiden in his Vermischte Bemerkungen, we find the following instance of the phenomenon I am describing:

The last two bars of the 'Death and the Maiden' theme ... it's possible to understand this first as an ordinary, conventional figure before coming to understand its deeper expression. I.e., before 
coming to understand that what is ordinary here is filled with significance.

'Fare well!'

'A whole world of pain is contained in these words'. How can it be contained in them? - It is bound up with them. The words are like an acorn from which an oak tree can grow. ${ }^{18}$

Here, Wittgenstein's strategy is the exact opposite of Clov's: faced with his metaphysical expression - the sublime evocation of the whole world of pain that lies in just two words - he prefers to delve further into the territory of the meaningless than to bring the words back home to the ordinary. (Perhaps this makes Wittgenstein more of a romantic than a skeptic here.) He asks the question 'How can it be contained in them?', which sounds as if he is about to correct himself, but rather does the opposite, by answering the question with a parable of an acorn and an oak tree that is purely figurative, and which, once again, evokes much, but means nothing. The gesturing towards an unspeakable sublime is here an unrecuperated gesture into meaninglessness.

A final example of what is at stake here is in evidence in one of Cavell's own examples. Consider this short exchange between Hamm and Clov:

HAMM: I'll give you nothing more to eat.

Clov: Then we'll die.

HAMM: I'll give you just enough to keep you from dying. You'll be hungry all the time.

Clov: Then we won't die. (Beckett, pp. 94-5) 
According to Cavell, this is a signal instance of when Beckett's words at first blush mean something other than what they say. He argues:

Clov can hardly be meaning what his words, taken together and commonly, would suggest, namely 'It makes no difference to me whether I live or die; I couldn't care less'. First in one sense that is so trivial a sentiment, at their stage, that it would get a laugh - at least from clear-headed Hamm. Second, it is not true. How could it make no difference when the point of the enterprise is to die to that world? ... And he could care less, because he's trying to leave (MWM, p. 125).

The alternative Cavell suggests is that Beckett's characters are deaf to implicatures: that is, that there is no implicit threat in Hamm's line 'I'll give you nothing more to eat', and that, hence, Clov is simply commenting on the logical consequences of Hamm's decisions. The words mean what they literally say i.e., they mean less than what they would ordinarily imply. ${ }^{19}$

Whilst this is an interesting way of looking at this dialogue, I would suggest that we can both have our cake and eat it here. Clov is also doing something else in this extract, whether he or Beckett mean him to or not. He is, once again, bringing Hamm's words back from their metaphysical to their everyday uses, taking them from the sublime to the ordinary. To be more precise, we can retain the sense of the threat in Hamm's words - 'I'll give you nothing more to eat' - and read Clov as commenting upon it as an ordinary statement. A 
threat to starve someone to death should evoke a reaction of shock, terror, and awe, which emotions would normally betoken the presence of the sublime, but Clov's reaction takes Hamm's threat away from the metaphysical and back to an ordinary, banal statement. Viewed this way, it is both a refusal to be drawn into the power that the sublime has to lead us away from the literal, and an acknowledgement of that power. In fact, it puts Clov in a position not unlike that of the skeptic.

Indeed, Noggle suggests that there is a "comparison between sublime experience and the alienating and absorbing powers of skepticism' ("WS", p. 612), in that both seem to open up an abyss beneath our feet into which our securities are plunged, whilst simultaneously - and perhaps paradoxically appearing inconsequential, since, in both cases, we soon emerge from the abyss unscathed. 'Like Hume's skepticism', says Noggle, 'the sublime aesthetic effect is distinguished by its capacity to alternately overturn everything and nothing at all, the proximity that it establishes between absolute precariousness and absolute security - the aesthetic unification of our terror of the ocean storm with our safety on shore' ("WS", p. 612).

This relationship between a Cavellian view of skepticism and a Wittgensteinian view of the sublime would be an apt way of drawing towards a conclusion. Since, for Cavell at least, skepticism is not (and cannot be) overcome by further knowledge, or certainty of belief, or insistence on either of these things, but only by a reframing of the ground of skepticism itself, so too the encounter with the meaninglessness beyond everyday language games that 
constitutes the Wittgensteinian sublime can be apprehended only by reframing the ground of the gesture towards the metaphysical, and returning (albeit temporarily) to the ordinary and the everyday. What can we conclude from this about Beckett's Endgame? That Hamm and Clov's fraught relationship with the language they use encapsulates and lays bare the ceaselessly, inevitably shifting transition between sense and nonsense that characterises the quest for certain forms of meaning. Like the very skepticism to which such a relationship with meaning must no doubt give rise, this quest is attainable only by the kind of therapeutic intervention that addresses the ongoing compulsion - to which readers of Beckett seem particularly addicted - of questing for such meanings in the first place.

Perhaps we would be right to take a skeptical view of the Wittgensteinian sublime, since, after all, we cannot $d o$ anything with it. Yet, at the same time, we cannot do without it, either, so skepticism in this case is 'not irrefutable, but obviously nonsensical' ${ }^{20}$ Either way, it makes no difference, and it makes all the difference in the world. We cannot help but plunge into the abyss of the Wittgensteinian sublime in search of so-called 'deeper' meanings to our words. But there are no more of these than there are sugar plums or pain killers, and it is simultaneously the Wittgensteinian sublime which shows us this. This is why Cavell is right to describe Beckett's technique in Endgame as 'not by supposing that there is a way out of language, but by fully accepting the fact that there is nowhere else to go' $(M W M$, p. 126). And yet I question whether anyone - even Beckett, even Hamm and Clov - can ever 'fully accept' the limits of language so simply, since we are doomed, time and again, to find ourselves propelled from 
the ordinary to the sublime and back again. That is why the final sentence of Cavell's essay on Beckett is such an apt conclusion: 'We hang between' ( $M W M$, p. 162). ${ }^{21}$

\section{$\underline{\text { NOTES }}$}

1. Theodor Adorno, "Trying to Understand Endgame" in Notes to Literature, trans. Shierry Weber Nicholsen (New York: Columbia U.P., 1991), p. 284. 2. For Deleuze on Beckett, see his "He Stuttered" in Gilles Deleuze and the Theatre of Philosophy, eds. Constantin V. Boundas and Dorothea Olkowski, trans. Constantin V. Boundas (London: Routledge, 1994), pp. 23-9, as well as "The Greatest Irish Film (Beckett's 'Film')" and "The Exhausted” in Gilles Deleuze: Essays Critical and Clinical, trans. Daniel W. Smith and Michael A. Greco (London: Verso, 1998), pp. 152-74; for Blanchot on Beckett, see his "Where Now? Who Now?" trans. Richard Howard in Samuel Beckett, ed. J. Birkett and K. Ince (London: Longman, 2000), pp. 93-8; for Badiou on Beckett see his On Beckett, ed. and trans. Nina Power and Alberto Toscano, (Manchester: Clinamen Press, 2003). A good account of these positions is Derval Tubridy's "The Absence of Origin: Beckett and Contemporary French Philosophy" in Literature and Philosophy: A Guide to Contemporary Debates ed. David Rudrum (London: Palgrave, 2006), pp. 24-36.

3. See Beckett and Philosophy, ed. Richard Lane (London: Palgrave: 2002).

4. Stanley Cavell, "Ending the Waiting Game: A Reading of Beckett's Endgame" in Must We Mean What We Say? A Book of Essays (updated ed., Cambridge: Cambridge U.P., 2002), pp. 115-162; hereafter abbreviated MWM. 
Martha Nussbaum, "Narrative Emotions: Beckett's Genealogy of Love" in Love's Knowledge (Oxford: Oxford U.P., 1990).

5. Simon Critchley, "Know Happiness - On Beckett" in Very Little ... Almost Nothing: Death, Philosophy, Literature (London: Routledge, 1997), pp. 141-180; p. 141-2.

6. It is precisely this aspect of Cavell's approach to which Benjamin Ogden objects. He asks, not unreasonably, 'What does it mean, ultimately, for a line in Endgame to be read literally?' See Benjamin H. Ogden, “What Philosophy Can’t Say About Literature: Stanley Cavell and Endgame”, Philosophy and Literature 33 (2009): pp. 126-138; p. 137.

7. Samuel Beckett, "Endgame" in his Complete Dramatic Works, (London: Faber, 1986), pp. 89-134; p. 111, p. 116.

8. See Jay Bernstein, "Philosophy's Refuge: Adorno in Beckett" in Philosophers' Poets, ed. David Wood (London: Routledge, 1990), pp. 177-191.

9. It is for this reason that I find the main thrust of Ogden's critique of Cavell's interpretation unconvincing. Ogden says of Cavell: 'His work of criticism is in search of something that it must find (that is, something that it claims to have found even when it may not have); what it must find is a work of literature that demonstrates the utility and validity of ordinary language philosophy' (Ogden, p. 126). On the contrary, Cavell's reading of Beckett - and indeed a large component of his broader philosophical project - tends rather to problematise what the ordinary might mean or might be, in ways not always as congenial to mainstream ordinary language philosophy as Ogden makes out. 10. Ludwig Wittgenstein, Philosophical Investigations, $2^{\text {nd }}$ ed., trans. G.E.M. Anscombe (Oxford: Blackwell, 1958), §304. 
11. Ludwig Wittgenstein, Tractatus Logico-Philosophicus, trans. D. F. Pears and

B. F. McGuiness, introd. Bertand Russell (London: Routledge, 2001).

12. James Noggle, “The Wittgensteinian Sublime”, New Literary History 27 (1996): pp. 605-619; p. 610. Hereafter abbreviated "WS".

13. Wittgenstein, Philosophical Investigations, §119.

14. This compulsion is, of course, described in much detail in Wittgenstein's Philosophical Investigations, where it forms one of the principal kinds of philosophical 'illness' or 'disease' that Wittgenstein's therapeutic approach seeks to address. In philosophy, we are told,

it is difficult as it were to keep our heads up, - to see that we must stick to the subjects of our every-day thinking, and not go astray and imagine that we have to describe extreme subtleties which in turn we are after all quite unable to describe with the means at our disposal. We feel as if we had to repair a torn spider's web with our fingers. $(\S 106)$.

Yet it is no less difficult to escape from the grip of metaphysical ideals once they have us in thrall:

The ideal, as we think of it, is unshakable. You can never get outside it; you must always turn back. There is no outside; outside you cannot breathe. - Where does this idea come from? It is like a pair of glasses on our nose through which we see whatever we look at. It never occurs to us to take them off. $(§ 103)$.

The Wittgensteinian project of philosophy as a form of therapeutic intervention would, on the evidence of these quotations, appear at least in part to take its cue from the richly problematic interrelation of ordinary, everyday language, and the 
metaphysical emptiness of the Wittgensteinian sublime - though that must form the subject for a more ambitious paper than this one.

(Incidentally, it might be of passing and coincidental interest that the vocabulary Wittgenstein uses in Investigations $§ 103$ is highly reminiscent of Hamm and Clov's, particularly of Hamm's blindness and Clov's inability to leave their shelter.)

15. Stanley Cavell, This New Yet Unapproachable America, (Albuquerque: Living Batch Press, 1989), p. 54, quoted by Noggle in "The Wittgensteinian Sublime", p. 607. It is worth pointing out that the idea of the sublime and its relation to Wittgenstein's thought crops up throughout This New Yet Unapproachable America. On the very first page, Cavell asserts 'I specify as philosophical work what Wittgenstein means by "leading words home", back from the sublime into our poverty' (p. 1), and elsewhere admires Wittgenstein's 'relentless project to, perhaps we can say, de-sublimize thought' (p. 71). More importantly, in an argument that closely anticipates Noggle's, he implicitly opposes the 'ordinary' with what he calls 'this frozen emptiness of sublimity' ( $\mathrm{p}$. 56).

16. See Marjorie Perloff "Witt-Watt: The Language of Resistance/The Resistance of Language" in Wittgenstein's Ladder: Poetic Language and the Strangeness of the Ordinary (Chicago: University of Chicago Press, 1996), pp. 115-143.

17. Wittgenstein, Philosophical Investigations, §524.

18. Ludwig Wittgenstein, Culture and Value, ed. G. H. von Wright, trans. Peter Winch (Oxford: Blackwell, 1980), p. 52e. 
19. Stanley Cavell has pointed out to me that for this reason, the cited passage neatly demonstrates that the literal can not be equated with the ordinary or the everyday: the ordinary and the literal meanings are divergent here. By the same token, we should avoid equating the literary with the metaphysical, or with some other 'extra-ordinary' term.

20. Wittgenstein, Tractatus Logico-Philosophicus, 6.51.

21. Thanks to Stanley Cavell, Marjorie Perloff, James Conant, Paola Marrati, James Noggle, Anselm Haverkamp, Christoph Menke, Katrin Trüstedt, Hent de Vries, Asja Szafraniec, Christopher Johnson. 